\title{
PENYEBAB KEJADIAN KEKURANGAN ENERGI KRONIS PADA IBU HAMIL RISIKO TINGGI DAN PEMANFAATAN ANTENATAL CARE DI WILAYAH KERJA PUSKESMAS JELBUK JEMBER
}

\author{
Factors of Chronic Energy Deficiency Incidence in High-Risk Pregnant Women and \\ Utilization of Antenatal Care in Jelbuk Public Health Center Jember District
}

\author{
Linda Syahadhatun Nisa ${ }^{1}$, Christyana Sandra ${ }^{2}$, Sri Utami ${ }^{3}$ \\ 1,2,3 Fakultas Kesehatan Masyarakat, Universitas Jember, Indonesia \\ E-mail: christyana_sandra@yahoo.com
}

\begin{abstract}
Background: The main cause of maternal death from 2010 to 2013 were bleeding, hypertension, infection, old labor, and abortion. From 2013 to 2015, public health center of Jelbuk had 50\% high-risk pregnant women more than total pregnancy.

Aim: The objective of this study was to identify factors of chronic energy loss incidence in high-risk pregnant women and service utilization of antenatal in Jelbuk public health center, Jember district.

Method: This research was an analytic research with cross-sectional approach. The population of this study was all high-risk mothers who experienced Chronic Energy Deficiency or Kekurangan Energi Kronis (KEK) in the work area of Jelbuk public health center with a total sample of 42 respondents selected by using simple random sampling.

Results: Results showed that most respondents had a complete use of ANC. There was a correlation between predisposing factors including age, knowledge, attitude and trust toward ANC utilization. There was no correlation between supporting factors including the variable of access to health service and officers' services with ANC utilization. There was a correlation between need factors (mother's health condition) with ANC utilization.

Conclusion: Overall, the respondents had completed Antenatal Care (ANC). The predisposing factors (age, knowledge, behavior, and trust) was correlated to the use of ANC, but the supporting factors was not correlated to ANC utilization. It is recommended to promote ANC to pregnant mothers with Chronic Energy Loss and strengthen cadres' performance for socialization.
\end{abstract}

Keywords: high-risk pregnant women, KEK, prenatal care.

\section{ABSTRAK}

Latar Belakang: Penyebab terbesar kematian ibu selama tahun 2010 sampai 2013 adalah pendarahan, hipertensi, infeksi, partus lama, dan abortus. Selama kurun waktu 2013 sampai 2015, Puskesmas Jelbuk merupakan puskesmas di Kabupaten Jember yang memiliki persentase perbandingan jumlah ibu hamil risiko tinggi lebih dari $50 \%$ dari jumlah total kehamilan.

Tujuan: Tujuan penelitian ini adalah mengidentifikasi hubungan antara faktor penyebab kejadian KEK pada ibu hamil risiko tinggi dengan pemanfaatan pelayanan antenatal di wilayah kerja Puskesmas Jelbuk Kabupaten Jember. Penelitian ini merupakan penelitian analitik dengan pendekatan cross sectional. Populasi penelitian ini adalah seluruh ibu risiko tinggi yang mengalami Kekurangan Energi Kronis (KEK) di wilayah kerja Puskesmas Jelbuk dengan jumlah sampel sebanyak 42 responden. Teknik pengambilan sampel menggunakan simple random sampling.

Hasil: Hasil penelitian menunjukkan bahwa sebagian besar responden memiliki pemanfaatan ANC yang lengkap. Terdapat hubungan antara faktor predisposisi meliputi variabel umur, pengetahuan, sikap dan kepercayaan terhadap pemanfaatan ANC. Tidak terdapat hubungan antara faktor pendukung meliputi variabel akses ke pelayanan kesehatan dan pelayanan petugas dengan pemanfaatan ANC. Terdapat hubungan antara faktor kebutuhan yaitu variabel (kondisi kesehatan ibu) dengan pemanfaatan ANC.

Kesimpulan: Dapat disimpulkan bahwa respondent menggunakan ANC lengkap. Faktor predisposisi (umur, pengetahuan, sikap, dan kepercayaan) berhubungan dengan penggunaan ANC, tapi faktor pendukung tidak berhubungan dengan pemanfaatan ANC. Disarankan untuk mempromosikan ANC kepada ibu hamil dengan KEK dan memperkuat kinerja kader untuk sosialisasi.

Kata kunci : ibu hamil risiko tinggi, KEK, pelayanan antenatal 


\section{PENDAHULUAN}

Penyebab terbesar kematian ibu selama tahun 2010 sampai 2013 adalah pendarahan, hipertensi, infeksi, partus lama, dan abortus (Kemenkes RI, 2014b). Pendarahan menempati persentase tertinggi penyebab kematian ibu (28\%), anemia dan Kekurangan Energi Kronis (KEK) pada ibu hamil menjadi penyebab utama terjadinya pendarahan dan infeksi yang merupakan faktor kematian utama ibu (Apriyanti, 2017). Salah satu bentuk faktor risiko pada ibu hamil adalah Kurang Energi Kronis (KEK) dengan lingkar lengan atas kurang dari $23,5 \mathrm{~cm}$, atau penambahan berat badan < $9 \mathrm{~kg}$ selama masa kehamilan (Kemenkes RI, 2015)

Kurang Energi Kronis (KEK) merupakan keadaan dimana ibu menderita kekurangan makanan yang berlangsung menahun (kronis) yang mengakibatkan timbulnya gangguan kesehatan pada ibu sehingga kebutuhan ibu hamil akan zat gizi yang semakin meningkat tidak terpenuhi (Depkes RI, 2002). Selama kurun waktu 2013 sampai 2015, Puskesmas Jelbuk merupakan Puskesmas di Kabupaten Jember yang memiliki persentase perbandingan jumlah ibu hamil risiko tinggi lebih dari $50 \%$ dari jumlah total kehamilan. Jumlah ini merupakan jumlah yang paling tinggi apabila dibandingkan dengan kecamatan lainnya. Pada tahun 2013 jumlah ibu hamil sebanyak 525 orang dengan persentase ibu hamil risiko tinggi sebesar 50,6\%. Tahun 2014 terdapat sebanyak 514 ibu hamil dengan persentase ibu hamil risiko tinggi sebesar $52 \%$ dan tahun 2015 terdapat sebanyak 516 ibu hamil dengan persentase ibu hamil risiko tinggi sebesar 52\% (Dinkes Jember, 2016). Pada tahun 2016, jumlah ibu hamil risiko tinggi sebanyak 312 orang dari 479 kehamilan (Sari dan Efendy, 2017). Salah satu penyebab tingginya kehamilan berisiko tinggi di Kecamatan Jelbuk diakibatkan oleh Kekurangan Energi Kronis (KEK) yang sampai dengan Agustus 2017, terdapat 193 ibu hamil risiko tinggi yang 75 orang diantaranya KEK.

Pelayanan kesehatan adalah setiap kegiatan dan atau serangkaian kegiatan yang dilakukan secara terpadu, terintegrasi dan berkesinambungan untuk memelihara dan meningkatkan derajat kesehatan masyarakat dalam bentuk pencegahan penyakit, peningkatan kesehatan, pengobatan penyakit, dan pemulihan kesehatan oleh pemerintah dan atau masyarakat (Puskesmas Jelbuk, 2016). Puskesmas sebagai unit pelayanan kesehatan tingkat pertama dan terdepan dalam sistem pelayanan kesehatan, melakukan upaya kesehatan wajib dan upaya kesehatan pilihan yang disesuaikan dengan kondisi, kebutuhan, tuntutan, kemampuan dan inovasi serta kebijakan pemerintah daerah setempat. Salah satu contoh pelayanan kesehatan adalah pelayanan antenatal.

Pelayanan antenatal mempunyai pengaruh yang baik terhadap pertumbuhan janin atau lama waktu mengandung, baik dengan diagnosis maupun dengan perawatan berkala terhadap adanya komplikasi kehamilan. Pertama kali ibu hamil melakukan pelayanan antenatal merupakan saat yang sangat penting, karena berbagai faktor risiko bisa diketahui seawal mungkin dan dapat segera dikurangi atau dihilangkan (Meikowati, 2014). Pelayanan gizi pada ibu hamil juga terintegrasi di dalam pelayanan antenatal terpadu. Setiap ibu hamil mempunyai risiko mengalami masalah gizi terutama KEK, hal tersebut yang mengharuskan semua ibu hamil menerima pelayanan antenatal yang komprehensif dan terpadu. Tujuan pelayanan antenatal terpadu salah satunya adalah pengobatan dan penanganan gizi yang tepat terhadap gangguan kesehatan ibu hamil termasuk masalah gizi terutama KEK.

Pemanfaatan pelayanan kesehatan adalah hasil dari proses pencarian pelayanan kesehatan oleh sesorang atau kelompok. Model sistem kesehatan (Health system model) yang berupa model kepercayaan kesehatan. Model ini terdapat 3 kategori utama dalam pemanfaatan pelayanan kesehatan, yaitu faktor predisposisi, faktor pendukung dan faktor kebutuhan (Notoatmodjo, 2014). Pada penelitian ini faktor predisposisi terdiri dari variabel umur, jarak kelahiran anak, tingkat pendidikan, tingkat pengetahuan ibu tentang penyebab KEK, sikap ibu tentang kejadian KEK dan kepercayaan terhadap pelayanan ANC, faktor pendukung (variabel akses ke pelayanan kesehatan dan pelayanan petugas) dan faktor kebutuhan (variabel riwayat penyakit dan kondisi kesehatan ibu).

Berdasarkan permasalahan tersebut, perlu dilakukan penelitian mengenai hubungan antara faktor penyebab kejadian KEK pada ibu hamil risiko tinggi dengan pemanfaatan pelayanan antenatal di wilayah kerja Puskesmas Jelbuk Kabupaten Jember sehingga ditetapkan tujuan penelitiannya adalah menganalisis hubungan antara faktor penyebab kejadian KEK pada ibu hamil risiko tinggi dengan pemanfaatan pelayanan antenatal di wilayah kerja Puskesmas Jelbuk Kabupaten Jember

\section{METODE}

Penelitian ini merupakan penelitian analitik dengan pendekatan cross sectional. Populasi penelitian ini adalah seluruh ibu risiko tinggi yang mengalami Kekurangan Energi Kronis (KEK) di wilayah kerja Puskesmas Jelbuk yang berjumlah 75 orang. Jumlah sampel sebanyak 42 responden dengan teknik pengambilan sampel menggunakan simple random sampling. Teknik pengumpulan data penelitian dilakukan dengan wawancara menggunakan kuesioner dan studi dokumentasi.

\section{HASIL DAN PEMBAHASAN}

\section{Distribusi Responden Berdasarkan Faktor Predisposisi}

Jarak kelahiran anak responden dalam penelitian ini dibedakan menjadi dua kategori yaitu $<2$ tahun dan $\geq 2$ tahun. Distribusi jarak kelahiran anak responden yaitu sebanyak 16 responden yang seluruhnya memiliki jarak kelahiran anak $\geq 2$ tahun $(100 \%)$ sedangkan responden yang lain baru memiliki anak atau kelahiran pertama sehingga pada hasil jarak kelahiran anak didapatkan data homogen. 
Sebagian besar responden dalam penelitian ini berasal dari ibu hamil risiko tinggi yang mengalami KEK dengan umur antara 20-35 tahun sebanyak 29 orang responden (69\%). Sebagian besar responden memiliki tingkat pendidikan terakhir tamat SD/Sederajat sebanyak 13 orang responden $(31 \%)$. Sebagian besar responden memiliki pengetahuan tinggi sebanyak 25 orang Distribusi Responden berdasarkan Faktor Pendukung

Sebagian besar responden dalam penelitian ini memiliki akses ke pelayanan kesehatan yang cukup baik yaitu sebanyak 25 orang responden $(59,5 \%)$. Sebagian besar responden menilai pelayanan petugas kesehatan cukup baik sebanyak 31 orang responden $(73,8 \%)$.

\section{Distribusi Responden Berdasarkan Faktor Kebutuhan}

Riwayat penyakit ibu dalam penelitian ini dibedakan menjadi dua kategori yaitu tidak memiliki riwayat penyakit dan memiliki riwayat penyakit. Berdasarkan hasil penelitian menunjukkan bahwa seluruh responden 42 orang (100\%) tidak memiliki riwayat penyakit sebelum hamil sehingga data riwayat penyakit ibu didapatkan data homogen. Sebagian besar responden dalam penelitian ini responden (59,5\%). Sebagian besar responden memiliki sikap yang baik sebanyak 22 orang responden $(52,4 \%)$. Sebagian besar responden memiliki kepercayaan yang tinggi sebanyak 24 orang responden $(57,1 \%)$.

tidak memiliki keluhan kesehatan saat kehamilan sebanyak 30 orang responden $(71,4 \%)$.

\section{Distribusi Responden Berdasarkan Pemanfaatan ANC}

Sebagian besar responden memiliki pelayanan ANC lengkap sebanyak 34 responden (81\%).

Tabulasi Silang antara Faktor Predisposisi dengan Pemanfaatan Pelayanan ANC

Tabel 1 menunjukkan bahwa sebagian besar responden yang memanfaatkan pelayanan ANC secara lengkap yaitu pada rentang umur 20-35 tahun. Analisis hubungan antara variabel umur dengan pemanfaatan ANC didapatkan nilai $p$-value $=0,033<0,05$ sehingga disimpulkan bahwa ada hubungan yang signifikan antara umur dengan pemanfaatan ANC.

Tabel 1. Tabulasi silang antara faktor predisposisi dengan pemanfaatan pelayanan ANC

\begin{tabular}{|c|c|c|c|c|c|c|c|}
\hline \multirow{3}{*}{ Faktor } & \multicolumn{4}{|c|}{ Pemanfaatan ANC } & \multicolumn{2}{|c|}{ Total } & \multirow[t]{3}{*}{$p$-value } \\
\hline & \multicolumn{2}{|c|}{ Tidak Lengkap } & \multicolumn{2}{|c|}{ Lengkap } & \multirow[b]{2}{*}{$\mathbf{n}$} & \multirow[b]{2}{*}{$\%$} & \\
\hline & $\mathbf{n}$ & $\%$ & $\mathbf{n}$ & $\%$ & & & \\
\hline \multicolumn{8}{|l|}{ Faktor Predisposisi } \\
\hline $\begin{array}{l}<20 \\
20-35\end{array}$ & $\begin{array}{l}0 \\
6\end{array}$ & $\begin{array}{c}0 \\
14,3\end{array}$ & $\begin{array}{l}10 \\
23\end{array}$ & $\begin{array}{l}23,8 \\
54,8\end{array}$ & $\begin{array}{l}10 \\
29\end{array}$ & $\begin{array}{c}23,8 \\
69\end{array}$ & \multirow[t]{2}{*}{0,033} \\
\hline $\begin{array}{l}>35 \\
\text { Jarak Kelahiran Anak }\end{array}$ & 2 & 4,8 & 1 & 2,9 & 3 & 7,1 & \\
\hline $\begin{array}{l}<2 \text { tahun } \\
\geq 2 \text { tahun } \\
\text { Tingkat Pendidikan }\end{array}$ & $\begin{array}{l}0 \\
3\end{array}$ & $\begin{array}{c}0 \\
18,8\end{array}$ & $\begin{array}{c}0 \\
13\end{array}$ & $\begin{array}{c}0 \\
81,3\end{array}$ & $\begin{array}{c}0 \\
16\end{array}$ & $\begin{array}{c}0 \\
100\end{array}$ & - \\
\hline Tidak/belum sekolah & 0 & 0 & 0 & 0 & 0 & 0 & \multirow{6}{*}{0,372} \\
\hline Tidak tamat SD & 1 & 2,4 & 4 & 11,8 & 5 & 11,9 & \\
\hline Tamat SD & 4 & 9,5 & 9 & 26,5 & 13 & 31 & \\
\hline Tamat SMP & 0 & 0 & 11 & 32,4 & 11 & 26,2 & \\
\hline Tamat SMA & 3 & 7,1 & 9 & 21,4 & 12 & 28,6 & \\
\hline $\begin{array}{l}\text { Tamat Perguruan Tinggi } \\
\text { Pengetahuan }\end{array}$ & 0 & 0 & 1 & 2,4 & 1 & 2,4 & \\
\hline Rendah & 6 & 14,3 & 11 & 26,2 & 17 & 40,5 & \multirow[t]{2}{*}{0,027} \\
\hline Tinggi & 2 & 4,8 & 23 & 54,8 & 25 & 59,5 & \\
\hline \multicolumn{8}{|l|}{ Sikap } \\
\hline Kurang baik & 7 & 16,7 & 13 & 31 & 20 & 47,6 & \multirow[t]{2}{*}{0,012} \\
\hline $\begin{array}{l}\text { Baik } \\
\text { Keperayaan }\end{array}$ & 1 & 2,4 & 21 & 50 & 22 & 52,4 & \\
\hline Sedang & 6 & 14,3 & 12 & 28,6 & 18 & 42,9 & \multirow[t]{2}{*}{0,041} \\
\hline Tinggi & 2 & 4,8 & 22 & 52,4 & 24 & 57,1 & \\
\hline
\end{tabular}

Seluruh responden memiliki jarak kelahiran anak $\geq 2$ tahun. Data yang didapatkan mengenai jarak kelahiran anak adalah data homogen sehingga tidak bisa dilakukan perbandingan dan uji variabel jarak kelahiran anak dengan pemanfaatan pelayanan ANC.

Responden yang memanfaatkan pelayanan ANC secara lengkap yaitu pada responden yang 
memiliki tingkat pendidikan terakhir tamat SMP/Sederajat sebesar. Didapatkan nilai $p$-value $=$ $0,372>0,05$ sehingga disimpulkan bahwa tidak ada hubungan yang signifikan antara tingkat pendidikan dengan pemanfaatan ANC

Sebagian besar responden yang memanfaatkan pelayanan ANC secara lengkap yaitu pada responden yang memiliki pengetahuan tinggi dan didapatkan nilai $p$-value $=0,027<0,05$ sehingga disimpulkan bahwa ada hubungan yang signifikan antara pengetahuan dengan pemanfaatan ANC.

Responden yang memanfaatkan pelayanan ANC secara lengkap yaitu pada responden yang memiliki sikap yang baik terhadapat pelayanan ANC dan didapatkan nilai $p$-value $=0,012<0,05$ sehingga disimpulkan bahwa ada hubungan yang signifikan antara sikap dengan pemanfaatan ANC.

Sebagian besar responden yang memanfaatkan pelayanan ANC secara lengkap yaitu pada responden yang memiliki kepercayaan tinggi terhadap pelayanan ANC dan didapatkan nilai $p$-value $=0,041<0,05$ sehingga disimpulkan bahwa ada hubungan yang signifikan antara kepercayaan dengan pemanfaatan ANC.

Tabel 2 menunjukkan sebagian besar responden yang memanfaatkan pelayanan ANC secara lengkap memiliki akses ke pelayanan kesehatan yang sedang dan didapatkan nilai $p$ value $=1,000>0,05$ sehingga disimpulkan bahwa tidak ada hubungan yang signifikan antara akses pelayanan kesehatan dengan pemanfaatan ANC.

Tabulasi Silang antara Faktor Pendukung
dengan Pemanfaatan Pelayanan ANC
Sebagian besar responden yang memanfaatkan pelayanan ANC secara lengkap yaitu pada responden yang menilai pelayanan petugas cukup baik dan didapatkan nilai $p$-value $=$ $1,000>0,05$ sehingga disimpulkan bahwa tidak ada hubungan yang signifikan antara pelayanan petugas dengan pemanfaatan ANC.

Tabel 2. Tabulasi silang antara faktor pendukung dengan pemanfaatan pelayanan ANC

$$
\text { Pemanfaatan ANC }
$$

Total

p-value

Faktor

$$
\text { Tidak Lengkap Lengkap }
$$

\begin{tabular}{|c|c|c|c|c|c|c|c|}
\hline & $\mathbf{n}$ & $\%$ & $\mathbf{N}$ & $\%$ & $\mathbf{n}$ & $\%$ & \\
\hline \multicolumn{8}{|c|}{ Faktor Pendukung } \\
\hline Sulit & 0 & 0 & 0 & 0 & 0 & 0 & \multirow{3}{*}{1,000} \\
\hline Sedang & 5 & 11,9 & 20 & 47,6 & 25 & 59,5 & \\
\hline Mudah & 3 & 7,1 & 14 & 33,3 & 17 & 40,5 & \\
\hline \multicolumn{8}{|c|}{ Pelayanan Petugas } \\
\hline Cukup baik & 6 & 14,3 & 25 & 59,5 & 31 & 73,8 & \multirow[t]{2}{*}{1,000} \\
\hline Baik & 2 & 4,8 & 9 & 21,4 & 11 & 26,2 & \\
\hline
\end{tabular}

Tabulasi Silang antara Faktor Kebutuhan dengan Pemanfaatan Pelayanan ANC

Tabel 3 menunjukkan bahwa sebagian besar responden yang memanfaatkan pelayanan ANC secara lengkap yaitu pada responden yang tidak memiliki riwayat penyakit (riwayat penyakit sebelum hamil). Data yang didapatkan mengenai riwayat kehamilan ibu adalah data homogen sehingga tidak bisa dilakukan perbandingan dan uji variabel riwayat penyakit ibu dengan pemanfaatan pelayanan ANC.

Sebagian besar responden yang memanfaatkan pelayanan ANC secara lengkap yaitu pada responden yang tidak memiliki keluhan saat kehamilan dan didapatkan nilai $p$-value $=$ $0,047<0,05$ sehingga disimpulkan bahwa ada hubungan yang signifikan antara kondisi kesehatan ibu dengan pemanfaatan ANC.

Sebagian besar responden dalam penelitian ini berasal dari ibu hamil risiko tinggi yang mengalami KEK dengan umur antara 20-35 tahun. Berdasarkan hasil tabulasi silang antara variabel didapatkan nilai $p$-value $=0,033<0,05$ sehingga disimpulkan bahwa ada hubungan yang signifikan antara umur dengan pemanfaatan ANC. Hasil penelitian ini sesuai dengan penelitian Sari dan Efendy yang menyatakan bahwa faktor umur ibu berpengaruh terhadap kunjungan antenatal care pada ibu hamil (Sari dan Efendy, 2017). Umur mempengaruhi daya tangkap dan pola pikir seseorang. Semakin bertambahnya usia akan semakin berkembang pula daya tangkap dan pola pikir, sehingga pengetahuan yang diperoleh semakin membaik, hal ini sebagai akibat dari pengalaman dan kematangan jiwanya, Sehingga semakin matang usia ibu hamil bisa mempengaruhi dalam menerima informasi tentang pemeriksaan kehamilan serta kunjungan selama hamil (Aprianti, 2012).

Hasil penelitian menunjukkan bahwa seluruh responden memiliki jarak kelahiran anak $\geq 2$ tahun sebanyak 16 orang responden dengan persentase $100 \%$. Responden dalam penelitian ini memiliki jarak kelahiran anak $\geq 2$ tahun karena bayak responden memiliki anak pertama ketika berumur muda ( $<20$ tahun), sehingga ketika memiliki anak kedua jarak kelahiran anaknya sudah jauh dari anak pertama. Hasil penelitian ini didapatkan data homogen sehingga tidak bisa dilakukan perbandingan dan uji variabel jarak kelahiran anak dengan pemanfaatan pelayanan ANC.

Hasil penelitian menunjukkan bahwa sebagian besar responden memiliki tingkat pendidikan terakhir tamat SD/Sederajat dan didapatkan nilai $p$-value $=0,372>0,05$ sehingga 
disimpulkan bahwa tidak ada hubungan yang signifikan antara tingkat pendidikan dengan pemanfaatan ANC.

Tidak adanya hubungan tingkat pendidikan karena sebagian besar responden meskipun memiiki tingkat pendidikan yang lebih tinggi tetapi tidak menjamin pengetahuan, pemahaman serta perilaku pemanfaatan ANC yang baik. Responden dalam penelitian ini memiliki pengetahuan, pemahaman serta perilaku pemanfaatan ANC yang belum baik sehingga pemanfaatan ANC responden tersebut menjadi tidak lengkap. Hasil penelitian ini tidak sesuai dengan hasil penelitian dari Handayani dan Budianingrum namun sesuai dengan hasil penelitian dari Sarminah yang menyatakan tidak ada hubungan antara tingkat pendidikan ibu dengan kunjungan antenatal (Handayani dan Budianingrum, 2011) (Veratamala, 2017).

Sebagian besar responden dalam penelitian ini memiliki pengetahuan tinggi dan didapatkan nilai $p$-value $=0,027<0,05$ sehingga disimpulkan bahwa ada hubungan yang signifikan antara pengetahuan dengan pemanfaatan ANC.
Pengetahuan responden yang tinggi mempengaruhi responden untuk memeriksakan kehamilannya (pemanfaatan ANC ke fasiitas kesehatan). Pengetahuan responden yang tinggi pada penelitian ini dipengaruhi oleh peran bidan yang sangat aktif dan antusias dalam memberikan himbauan kepada responden mengenai pentingnya pemanfaatan ANC. Menurut Notoatmodjo menyebutkan bahwa pengetahuan atau kognitif merupakan domain yang sangat penting untuk terbentuknya tindakan seseorang. Apabila perilaku didasari oleh pengetahuan, kesadaran dan sikap yang positif maka perilaku tersebut akan bersifat langgeng (long sting) (Notoadmodjo, 2010).

Sebagian besar responden dalam penelitian ini memiliki sikap yang baik. Hasil penelitian didapatkan nilai $p$-value $=0,012<0,05$ sehingga disimpulkan bahwa ada hubungan yang signifikan antara sikap dengan pemanfaatan ANC. Penelitian Suandewi et.al menunjukkan bahwa ada hubungan antara sikap ibu hamil dengan kunjungan ANC (Suandewi et al, 2015).

Tabel 3. Tabulasi silang antara faktor kebutuhan dengan pemanfaatan pelayanan ANC

Faktor

Kelelahan Kerja

Total

p-value

Tidak Lengkap Lengkap

$\begin{array}{llllll}\mathbf{N} & \% & \mathbf{N} & \% & \mathbf{n} & \%\end{array}$

Faktor Penguat

\section{Riwayat Penyakit}

Tidak ada

Ada

Kondisi Kesehatan

Tidak ada keluhan

Ada keluhan

Sikap mempengaruhi kecenderungan untuk membentuk sebuah perilaku pada seseorang sehingga jika sikap sesorang itu positif maka akan cenderung muncul sebuah perilaku yang positif. Sebaliknya jika sikap seseorang tersebut negatif maka akan cenderung muncul perilaku yang negatif. Sebagian besar responden memiliki sikap yang baik sehingga responden memiliki kecenderungan untuk memanfaatkan pelayanan ANC. Sikap positif dapat merespon atau menilai pentingnya pemeriksaan kehamilan sehingga sikap responden dalam melakukan kunjungan ANC dapat ditingkatkan baik dengan cara pemberian penyuluhan ataupun edukasi lainnya (Kemenkes $\mathrm{RI}, 2015$ ).

Sebagian besar responden dalam penelitian ini memiliki kepercayaan yang tinggi. Hasil penelitian didapatkan nilai $p$-value $=0,041<0,05$ sehingga disimpulkan bahwa ada hubungan yang signifikan antara kepercayaan dengan pemanfaatan ANC. Hasil penelitian ini sesuai dengan penelitian Tasliah et.al yang menyatakan bahwa terdapat hubungan antara kepercayaan dengan pemanfaatan ANC (Tasliah et al, 2017). Sebagian besar responden memiliki kepercayaan yang tinggi terhadap pelayanan ANC, karena responden tersebut sudah memahami akan pentingnya pemanfaatan pelayanan kesehatan, namun masih banyak responden yang memiliki kepercayaan kurang karena ada beberapa saran atau informasi dari petugas kesehatan (bidan) yang dilaksanakan oleh responden, misalnya saran untuk rutin mengkonsumsi makanan tambahan yang diberikan oleh posyandu namun ada beberapa saran dari orang tua responden yang juga diterima serta dilaksanakan oleh responden. Kepercayaan sesorang akan sesuatu hal atau dukungan dari orang lain untuk meyakini suatu hal akan mempengaruhi cara berperilaku orang tersebut (Notoadmodjo, 2010).

Sebagian besar responden memiliki akses ke pelayanan kesehatan yang sedang dan didapatkan nilai $p$-value $=1,000>0,05$ sehingga disimpulkan bahwa tidak ada hubungan yang signifikan antara akses pelayanan kesehatan dengan pemanfaatan ANC. Hasil penelitian ini sesuai dengan penelitian Erlina et al yang menyatakan bahwa tidak ada hubungan antara akses atau keterjangkauan dengan pemeriksaan ANC (Erlina et al, 2013). Tidak adanya hubungan antara akses ke pelayanan kesehatan dengan pemanfaatan ANC dikarenakan sebagian besar responden memiliki akses ke pelayanan kesehatan yang mudah serta letak posyandu yang dekat 
dengan sasaran dimanfaatkan dengan baik oleh bidan dan kader sehingga mampu menarik responden untuk datang memeriksakan kehamilannya. Posyandu merupakan salah satu tempat fasilitas pelayanan kesehatan yang menyediakan pelayanan kesehatan salah satunya Antenatal Care. Pelayanan Antenatal Care di posyandu bisa dilakukan dengan syarat harus terdapat dokter atau bidan pada saat melakasanakan Antenatal Care. Puskesmas Jelbuk menggunakan posyandu sebagai wadah untuk melaksanakan pemanfaatan pelayanan Antenatal Care di wilayah kerjanya dengan tujuan untuk memudahkan menjangkau ibu hamil.

Hasil penelitian menunjukkan sebagian besar responden dalam penelitian ini menilai pelayanan petugas kesehatan cukup baik. Hasil penelitian ini didapatkan nilai $p$-value $=1,000>0,05$ sehingga disimpulkan bahwa tidak ada hubungan yang signifikan antara pelayanan petugas dengan pemanfaatan ANC. Kualitas pelayanan petugas merupakan salah satu faktor yang menentukan dalam menjaga keberlangsungan suatu organisasi, semakin baik dan sesuai pelayanannya dengan kebutuhan pengguna jasa maka akan membantu mewujudkan kepuasan pengguna jasa tersebut (Wardhani, 2015). Tidak adanya hubungan dikarenakan pelayanan petugas (bidan) sudah baik. Pelayanan petugas yang baik tersebut dilihat dari keramahan, ketanggapan, perhatian, komunikasi, kemudahan petugas untuk dihubungi serta pelayanan yang memberikan rasa aman dan percaya. Pelayanan petugas yang baik membuat responden akan sangat antusias untuk memeriksakan kehamilannya sehingga permasalahan saat kehamilan seperti risiko tinggi KEK dapat ditanggulangi lebih dini dengan pemberian makanan tambahan serta informasi pada responden.

Hasil penelitian menunjukkan seluruh responden (100\%) tidak memiliki riwayat penyakit (penyakit yang pernah di derita sebelum hamil) sehingga tidak bisa dilakukan perbandingan dan uji variabel riwayat penyakit dengan pemanfaatan pelayanan ANC. Sebagian besar responden dalam penelitian ini berumur 20 sampai 35 tahun, sehingga risiko riwayat kehamilannya kecil. Hal tersebut juga sesuai dengan teori dari Veratamala yang menyatakan bahwa semakin tua usia seorang ibu maka riwayat kesehatan atau penyakit yang diderita semakin tinggi risiko terjadinya mulai dari hipertensi, diabetes, TBC, dan lain-lain yang riwayat penyakit tersebut akan memperburuk atau mengganggu kehamilan (Veratamala, 2017). Hasil penelitian menunjukkan sebagian besar responden dalam penelitian ini tidak memiliki keluhan kesehatan saat kehamilan. Hasil penelitian didapatkan nilai $p$-value $=0,047<0,05$ sehingga disimpulkan bahwa ada hubungan yang signifikan antara kondisi kesehatan ibu dengan pemanfaatan ANC.

Menurut penelitian Karamelka menyatakan bahwa ada pengaruh antara kondisi ibu hamil dengan pemanfaatan ANC, penelitian tersebut juga menjelaskan bahwa ketika seseorang dalam kondisi yang tidak sehat atau mengalami gangguan, maka mereka akan lebih sadar untuk memanfaatkan pelayanan kesehatan dengan cukup agar kondisi mereka menjadi baik (Karamelka, 2015). Ibu hamil yang mengalami keluhan atau komplikasi saat hamil maka mereka akan lebih waspada dan lebih cermat dalam menjalani setiap proses kehamiannya. Penelitian ini juga sesuai dengan teori Anderson, yaitu keadaan kondisi saat periksa hamil yang dirasa atau di persepsi ibu terhadap berat ringannya penyakit atau keluhan atau gejala yang dirasakan ibu sebagai gangguan kesehatan selama kehamilannya. Pada penelitian ini diketahui bahwa responden mengalami sakit seperti mual berlebihan, batuk sampai satu minggu, asma, dan pendarahan pada kehamilannya.

\section{SIMPULAN}

Berdasarkan dari hasil penelitian dan pembahasan penelitian maka dapat diperoleh kesimpulan sebagai berikut, sebagian besar responden memiliki pemanfaatan ANC yang lengkap. Terdapat hubungan antara faktor predisposisi meliputi variabel umur, pengetahuan, sikap dan kepercayaan terhadap pemanfaatan ANC sedangkan jarak kelahiran anak didapatkan data homogen. Tidak terdapat hubungan antara faktor pendukung meliputi variabel akses ke pelayanan kesehatan dan pelayanan petugas dengan pemanfaatan ANC. Terdapat hubungan antara faktor kebutuhan yaitu variabel (kondisi kesehatan ibu) dengan pemanfaatan ANC, sedangkan riwayat penyakit didapatkan data homogen sehingga tidak bisa dilakukan uji hubungan dan perbandingan.

Saran yang diberikan kepada pihak Puskesmas Jelbuk, Dinas Kesehatan Kabupaten Jember dan peneliti selanjutnya adalah perlu adanya penyuluhan secara berkala kepada ibu hamil KEK mengenai pemeriksaan kehamilan (ANC) yang di dalamnya juga menjelaskan tentang bahaya KEK dan pentingnya status gizi yang baik. Penyuluhan dapat dilakukan dengan bantuan media poster, leaflet, brosur, video, dan media lainnya, Penyuluhan kepada ibu hamil KEK mengenai pemeriksaan kehamilan selama ini belum pernah dilakukan secara berkala, hanya ketika ada kasus saja penyuluhan dilakukan. Puskesmas perlu melaksanakan pelatihan pembuatan PMT berbasis makanan lokal agar ibu hamil mudah mendapatkan bahan makanan yang diperlukan, pemberdayaan dan penguatan kinerja kader untuk sosialisasi, kunjungan rumah dan pendampingan ibu hamil, meningkatkan kerja sama lintas sektor dengan KUA untuk memberikan konseling tentang gizi dan kehamilan kepada calon pengantin.

Bagi Dinas Kesehatan Kabupaten Jember perlu meningkatkan kualitas dan kuantitas pelayanan gizi pada ibu hamil yang terintegrasi di dalam pelayanan Antenatal terpadu, seperti melakukan penambahan jumlah PMT untuk puskesmas yang memiliki jumlah ibu hamil KEK tinggi. Bagi peneliti selanjutnya, dapat meneliti kembali variabel seperti jarak kelahiran anak dan riwayat penyakit dengan populasi yang lebih besar sehingga mendapatkan data yang heterogen serta meneliti variabel yang lainnya seperti kepersertaan jaminan kesehatan dan penilaian kilinik (evaluated) 


\section{DAFTAR PUSTAKA}

Aprianti, E. (2017) Gambaran Kejadian Kekurangan Energi Kronis (KEK) pada lbu Hamil di Puskesmas Kasihan I Bantul Yogyakarta Tahun 2017. SEKOLAH TINGGI ILMU KESEHATAN JENDERAL ACHMAD YANI YOGYAKARTA. Available at: http://repository.unjaya.ac.id/2347/.

Departemen Kesehatan Republik Indonesia (1995) Pedoman dan Petunjuk Pelaksanaan Penanggulangan Kekurangan Energi Kronis pada Ibu Hamil. Departemen Kesehatan Republik Indonesia.

Departemen Kesehatan Republik Indonesia (2002) Program Perbaikan Gizi Makro. Departemen Kesehatan Republik Indonesia.

Dinas Kesehatan Kabupaten Jember (2016) Jumlah Ibu Hamil Risiko Tinggi di setiap Kecamatan di Kabupaten Jember. Jember.

Handayani, S. and Budianingrum, S. (2011) 'Analisi Faktor Yang Mempengaruhi Kekurangan Energi Kronis Pada lbu Hamil Di Wilayah Puskesmas Wedi Klaten', Jurnal IImu Kebidanan, 1(1), pp. 42-60. Available at: http://ejournal.stikesmukla.ac.id/index.php/in volusi/article/view/17/13.

Karamelka, W. (2015) Faktor Yang Mempengaruhi Pemanfaatan Pelayanan Antenatal Care Di Wilayah Kerja Puskesmas Kec.Wolo Kabupaten Kolaka Tahun 2015. Universitas Halu Oleo. Available at: http://sitedi.uho.ac.id/uploads_sitedi/F2DA09 159_sitedi_WARTINA.

Kementerian Kesehatan (2015) Profil Kesehatan Indonesia 2014, Kementerian Kesehatan Republik Indonesia. Kementerian Kesehatan Republik Indonesia. doi: 10.1037/00223514.51.6.1173.

Kurnia Indriyanti Purnama Sari (2017) 'Analisis Faktor Yang Berpengaruh Terhadap Kunjungan Antenatal Care', Jurnal Keperawatan dan Kebidanan, 9(1), pp. 93113. Available at: http://jurnalonline.Ippmdianhusada.ac.id/inde x.php/jkk/article/view/108.

Meikowati, F. P. D. (2014) Analisis Perbedaan Faktor Pemanfaatan Pelayanan Antenatal antara Puskesmas Wuluhan dan Puskesmas Arjasa Kabupaten Jember. Universitas Jember.

Notoatmodjo, S. (2010) Metodologi Penelitian Kesehatan. Jakarta: Rineka Cipta.

Notoatmodjo, S. (2014) IImu Perilaku Kesehatan. Jakarta: Rineka Cipta.

Puskesmas Jelbuk Jember (2016) Profil Puskesmas Jelbuk Jember. Jember.

Rahma Erlina, TA Larasati and Betta Kurniawan (2013) 'Faktor-Faktor Yang Mempengaruhi Ibu Hamil Terhadap Kunjungan Pemeriksaan Kehamilan di Puskesmas Rawat Inap Panjang Bandar Lampung', Medical Jurnal of Lampung University, 2(4), pp. 29-34. Available http://juke.kedokteran.unila.ac.id/index.php/ majority/article/view/59/58.

Sarminah (2012) Faktor-Faktor yang Berhubungan dengan Kunjungan Antenatal Care di Provinsi Papua Tahun 2010 (Analisis Data Sekunder Riskesdas 2010), Universitas Indonesia. Universitas Indonesia. Available at:

http://lontar.ui.ac.id/file?file=digital/20296280 -S-Sarminah.pdf.

Suandewi, A. A. P. P. and, Christina Pernatun Kismoyo, S. (2015) 'Sikap Ibu Hamil dengan Kepatuhan Kunjungan Antenatal Care Pertama (K1)', Jurnal IImu Kebidanan, III(1), pp. 33-38.

Tasliah, Widagno, L. and P, P. N. (2017) 'FaktorFaktor Yang Berhubungan Dengan Kunjungan Antenatal Care (ANC) Padaibu Hamil Di Wilayah Kerja Puskesmas Candilamakota Semarang', JURNAL KESEHATAN MASYARAKAT (e -Journal), 5(3), pp. 637-644. Available at: https://ejournal3.undip.ac.id/index.php/jkm/ar ticle/view/17411/16666.

Veratamala, A. (2017) 'Risiko Hamil di Atas Usia 35 Tahun (dan Cara Mengatasinya)', Hello Sehat. Available at: https://hellosehat.com/kehamilan/kandungan /yang-harus-diketahui-tentang-kehamilan-diatas-35-tahun/ (Accessed: 5 February 2018).

Wardhani, A. T. (2015) Skripsi Kualitas Pelayanan di Rumah Sakit Umum Daerah Syekh Yusuf Gowa. UNIVERSITAS HASANUDDIN FAKULTAS. Available at: http://repository.unhas.ac.id/handle/1234567 89/18008. 